\title{
Vitamin B1 Measurement
}

National Cancer Institute

\section{Source}

National Cancer Institute. Vitamin B1 Measurement. NCI Thesaurus. Code C74896.

The determination of the amount of Vitamin B1 present in a sample. 